\title{
Diversity of Yeasts Involved in Cocoa Fermentation of Six Major Cocoa-Producing Regions in Ivory Coast
}

\author{
Odilon Koffi, PhD Student, \\ Lamine Samagaci, PhD., \\ Bernadette Goualie, PhD., \\ Sebastien Niamke, PhD., Professor,
} Laboratoire de Biotechnologie, UFR Biosciences, Université Felix Houphouët-Boigny Abidjan, Côte d'Ivoire

Doi: 10.19044/esj.2017.v13n30p496 URL:http://dx.doi.org/10.19044/esj.2017.v13n30p496

\begin{abstract}
Cocoa beans (Theobroma cacao L.) are the raw material for chocolate production. Fermentation of cocoa pulp is crucial for developing chocolate flavor precursors. This fermentation is led by a succession of complex microbial communities where yeasts play key roles during the first stages of the process. In this study, we identified and analyzed the growth dynamics of yeasts involved in cocoa bean fermentation of six major cocoaproducing regions in Ivory Coast. A total of 743 yeasts were isolated, and were identified by sequencing of D1/D2 regions of $26 \mathrm{~S}$ rDNA gene. These isolates included 11 species with a predominance of Pichia kudriavzevii (44,81\%), Pichia kluyveri (20,99 \%) and Saccharomyces cerevisiae (18,97 $\%)$ respectively. In addition, the length polymorphism of the genetic marker ITS1-5.8S-ITS2 and PCR-RFLP analysis revealed an intraspecific diversity within the three-main species involved in cocoa fermentation of six major local regions in Ivory Coast. This intraspecific diversity could be exploited for selecting appropriate starter cultures.
\end{abstract}

Keywords: Cocoa, fermentation, yeast, diversity, PCR-RFLP

\section{Introduction}

Cocoa fermentation is a crucial step of post-harvest processing of cocoa. It's a spontaneous process in while the different flavor and aroma precursors of cocoa beans desired in chocolate industry are produced (Schwan \& Wheals, The microbiology of cocoa fermentation and its role in chocolate quality, 2004. De Vuyst, Lefeber, Papalexandratou, \& Camu, 2010). Cocoa fermentation efficiency requires the activity of successive indigenous microorganisms' consortia, including yeasts, lactic acid and 
acetic acid bacteria, and Bacillus bacteria (Ouattara, et al., 2008. Ho V. , Zhao, Srzednicki, \& Fleet, 2013). Among these microorganisms, yeasts are essentials because considered as initiators of this process (Soumahoro, et al., 2015. Ho, Zhao, \& Fleet, 2014). Indeed, without yeasts in cocoa fermentation, the chocolate obtained after manufacturing is without savour nor flavor and depreciated by (Ho, Zhao, \& Fleet, 2014). Yeasts involving in cocoa fermentation play crucial roles in the cocoa pulp fermentation process, including the production of ethanol and organic acids, which are believed to arrest germination of the cocoa seeds and contribute to essential chemical conversions inside the cocoa beans (Hansen, Del Olmo, \& C., 1998) In fact, most yeasts initiate an alcoholic fermentation of the pulp sugars, generating ethanol which, along with acetic acid, enters the bean to kill the embryo and trigger endogenous biochemical reactions that produce the chocolate flavor precursors (De Vuyst, Lefeber, Papalexandratou, \& Camu, 2010). Apart from alcoholic fermentation, some yeasts such Pichia kudriavzevii and Saccharomyces cerevisiae are able to produce volatile aroma compounds that contribute as precursors of chocolate flavor (Verstrepen, et al., 2003. Kostinek, et al., 2008). Others yeasts mainly Pichia kluyveri and Kluyveromyces marxianus produce pectinolytic enzymes which are believed to play a central role in the degradation of the viscous pectin-rich pulp (Schwan, Rose, \& Board, 1995. Lopez \& Dimick, 1995). The action of yeast pectinolytic enzyme is essential for the growth of other microorganisms involving in cocoa fermentation (Schwan, Rose, \& Board, 1995).

This importance of yeasts in cocoa fermentation explain why these microorganisms were mostly studied in order to assess their diversity and identify different key species which could be exploited for selecting appropriate starter cultures in cocoa fermentation.

Thus, in Ghana (near New Tafo and Old Tafo), Saccharomyces cerevisiae, Pichia kudriavzevii, and Hanseniaspora opuntiae were founded as dominant yeast species (Daniel, Vrancken, Takrama, Camu, \& De Vuyst, 2009), while Candida tropicalis was yeast species dominant in Indonesia (precisely in East Java), (Ardhana \& Fleet, 2003). At San Francisco de Macoris, in Dominican Republic, (Lagunes-Galvez, Loiseau, Paredes, Barel, \& Guiraud, 2007) reported that Candida inconspicua was the most abundant and persistent yeast during cacao fermentation. From Itajuípe, Bahia State in Brazil, S. cerevisiae and Hanseniaspora sp. were dominant yeasts (Pereira, Miguel, Ramos, \& Schwan, 2012) while P. kudriavzevii, S. cerevisiae, Saccharomycopsis crataegensis and Hanseniaspora guilliermondii were the predominant yeasts isolated from fermented cocoa bean mass in the Mexican state of Tabasco (Arana-Sánchez, et al., 2015). All researches indicate that yeast populations involved in cocoa fermentations vary from country to country, from local region to local region, around the world ((Nielsen, 
Hønholt, Tano-Debrah, \& Jespersen, 2005. Daniel, Vrancken, Takrama, Camu, \& De Vuyst, 2009. Romero-Cortes, Robles-Olvera, RodriguezJimenes, \& Ramírez-Lepe, 2012). This variability of yeast species from area to area could be impact the final cocoa beans quality in fine chocolate. Indeed, the spontaneous nature of cocoa bean fermentations may be the source of variable cocoa beans broad quality (Maura, et al., 2016). This situation causes huge economic losses for cocoa-producing countries estimated among 200 billion FCFA/year in Ivory Coast (ANADER, 2014). That why, many investigations suggest the use of microbial starter culture to improve fermentation process. In this context, the yeast species as Pichia kudriavzevii, Saccharomyces cerevisiae, Pichia klyuveri and Candida sp., were used as starter to control cocoa fermentation (Crafack, et al., 2013. Mahazar, et al., 2015. Meersman, et al., 2016. Pereira, et al., 2017). These different species improved cocoa fermentation process and the chocolate quality, but results obtained are still insufficient for cocoa fermentation process standardization. Therefore, the research to select appropriate yeast starter must be continuous and a perfect knowledge of the diversity of yeast strains involved in cocoa fermentation is necessary to reach this goal. Thus, considering the variability of yeasts involving in cocoa fermentation of country to country and local region to local region within the same country, investigations must be carry out in the different cocoa-producing/exporting areas with a view to a perfect knowledge fermented cocoa yeasts.

From Ivory Coast, first cocoa producer/exporter, on 17 cocoaproducing regions, only yeast involving in cocoa fermentation of two local regions, including Me and Agneby-Tiassa was studied in order to assess molecular diversity and to select appropriate yeast starter (Koné, et al., 2016. Samagaci, Ouattara, Niamké, \& Lemaire, 2016). None information exists concerning yeast species involving in cocoa fermentation from the other local regions of Ivory Coast.

The aim of this study is to assess molecular diversity within yeast populations involved in cocoa fermentation from six major local regions of Ivory Coast in order to investigate the keys species for selecting appropriate yeasts starters for Ivorian cocoa fermentation.

\section{Materials and Methods}

\section{Fermentations, isolations and growth conditions of yeasts}

The cocoa pods were harvested in October 2015 from six (6) major cocoa-producing regions of Ivory Coast: Gôh $\left(6^{\circ} 07^{\prime} 60^{\prime \prime} \mathrm{N}, 5^{\circ} 55^{\prime} 60^{\prime}\right.$ ' W),

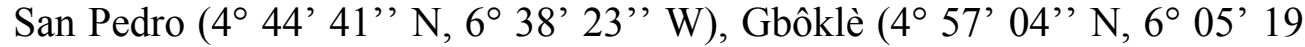
W), Haut-Sassandra ( $\left.6^{\circ} 53^{\prime} \mathrm{N}, 6^{\circ} 27^{\prime} \mathrm{W}\right)$, Cavally $\left(6^{\circ} 32^{\prime} 37^{\prime}\right.$ ' $\mathrm{N}, 7^{\circ} 29^{\prime}$ $37^{\prime}$ ' W), Tonkpi $\left(7^{\circ} 24^{\prime} \mathrm{N}, 7^{\circ} 33^{\prime} \mathrm{W}\right)$. One hundred (100) $\mathrm{Kg}$ of cocoa beans, constituted of mixed genotypes (Forastero, Trinitario, Criollo), were 
fermenting using traditional heap method with banana leaves, during 6 days. One hundred (100) g samples were regularly taken each $12 \mathrm{~h}$ to fermentation time. The numeration and isolation of yeasts were carried out using the decimal dilution method (Pereira, Miguel, Ramos, \& Schwan, 2012). After approximate decimal dilution in sterile saline solution, the fresh fermented samples were plated onto MYGP agar $(3 \mathrm{~g} / \mathrm{L}$ yeast extract; $3 \mathrm{~g} / \mathrm{L}$ malt extract, $5 \mathrm{~g} / \mathrm{L}$ bactopeptone; glucose $10 \mathrm{~g} / \mathrm{L}$ and agar $15 \mathrm{~g} / \mathrm{L}$ ) containing 100 $\mathrm{mg} / \mathrm{L}$ chloramphenicol (Sigma). Yeasts strains were identified morphologically after 3 days incubation at $30{ }^{\circ} \mathrm{C}$, and then maintained in glycerol $(20 \%)$ at $-20{ }^{\circ} \mathrm{C}$ for further studies.

\section{Physicochemical analysis}

\subsection{Temperature and $\mathrm{pH}$ determination}

The temperature was recorded directly on mass fermenting with a precision thermoter (ALLA, France). The $\mathrm{pH}$ determination of cocoa beans followed the protocol of Senanayake, Jansz, \& Buckle, (1997) For pulp pH, $10 \mathrm{~g}$ cocoa beans were shaken in $100 \mathrm{~mL}$ of MiliQ water for $15 \mathrm{~min}$. The beans were separated by decanting and the $\mathrm{pH}$ of the supernatant was measured using a digital $\mathrm{pH}$ meter (EUTECH, Germany).

\subsection{Titratable acidity determination}

Titratable acidity was determined according to the method AOAC, (1990). Cocoa beans were mixed in MilliQ water and filtrate. Titration was carried out by pouring drop by drop a solution of $\mathrm{NaOH}(0.1 . \mathrm{N})\left(\mathrm{V}_{1}\right)$ in 10 $\mathrm{mL}$ of filtrate in the presence of phenolphthalein (3 drops). Titratable acidity was expressed milliequivalents (meq) for $1 \mathrm{~g}$ of fresh matter by the following relation:

\section{Titrable acidity $(\mathrm{meq} / \mathrm{g})=\left(\mathbf{N} \times \mathrm{V}_{1} \times 10^{2}\right) /\left(\mathbf{m} \times V_{0}\right)$}

$\mathrm{V}_{0}$ : volume $(\mathrm{mL})$ of the taken filtrate, $\mathrm{V}_{1}$ : volume $(\mathrm{mL})$ of poured $\mathrm{NaOH}, \mathrm{N}$ : normality of $\mathrm{NaOH}, \mathrm{m}$ : mass sample.

\subsection{Reducing sugars determination}

The quantity of reducing sugars was determined by using the method of Bernfeld, (1955). Before to quantify reducing sugars, the extraction of water-soluble sugars of pulp was carried out according to the method of Agbo, Uebersax, \& Hosfieldn, (1985). Thus, $5 \mathrm{~g}$ of cocoa beans were homogenized in $50 \mathrm{~mL}$ distilled water at $60{ }^{\circ} \mathrm{C}$ until cooling at ambient temperature. The mixture was then filtered on filter paper (Whatman, $\varnothing 185$ $\mathrm{mm}$ ) and the filtrate was supplemented with $100 \mathrm{~mL}$ of distilled water. To $100 \mu \mathrm{L}$ of water-soluble sugar extracts were added $200 \mu \mathrm{L}$ of DNS (3,5dinitrosalycilic acid). Then, the solution was heated during $5 \mathrm{~min}$. After cooling, $2 \mathrm{~mL}$ of distilled water were added and the optical density was 
obtained with a spectrophotometer (PIOWAY, Singapore) at $540 \mathrm{~nm}$ against a blank. A standard curve was established with glucose solution $(1 \mathrm{mg} / \mathrm{mL})$ and the quantity of reducing sugars of each sample was obtained from the regression equation established using the standard curve.

\section{Identification of yeast species}

\subsection{Yeast DNA extraction and PCR amplification}

Yeasts were grown at $30{ }^{\circ} \mathrm{C}$ to the mid-log phase in YPD medium before harvesting. Yeast genomic DNA was extracted using the classic phenol/chloroform method described by Hoffman, (2001) and used as matrix for the PCR reactions. All PCR reactions were performed using a thermocycler (Mycycler, Bio Rad, USA) in a final volume of $50 \mu \mathrm{L}$ containing $1 \mu \mathrm{L}$ of DNA extract, $1 \mathrm{U}$ Taq DNA polymerase (New England BioLabs), $5 \mu \mathrm{L}$ 10X magnesium-free buffer, $1.5 \mathrm{mM} \mathrm{MgCl}_{2}, 0.2 \mu \mathrm{M}$ of each primer, $200 \mu \mathrm{M}$ dNTP (Euromedex, France).

The ITS1/ITS2 region of the 5.8S rDNA was PCR amplified as described by Zarzoso, Belloch, Uruburul, \& Quero, (1999) using the eukaryotic universal primers ITS1 (5', TCCGTAGGTGAACCTGCGG 3') and ITS4 (5'TCCTCCGCTTATTGATATGC 3').

The ITS1/ITS2 PCR program started by an initial denaturation at $95{ }^{\circ} \mathrm{C}$ for $5 \mathrm{~min}$, followed by 35 cycles $\left(94^{\circ} \mathrm{C}\right.$ for $1 \mathrm{~min}, 55.5^{\circ} \mathrm{C}$ for $1 \mathrm{~min}, 72^{\circ} \mathrm{C}$ for $2 \mathrm{~min}$ ) and ended by a final extension at $72{ }^{\circ} \mathrm{C}$ for $10 \mathrm{~min}$. The amplified products were used then for digestion with restriction enzymes during RFLP. The D1/D2 region of $26 \mathrm{~S}$ rDNA was PCR amplified as described by Hamdouche, et al. (2015) using the eukaryotic universal primer gc-NL1 (5' CGCCCGCCGCGCGCGGCGGGCGGGGCGGGGGCCATATCAATAAG CGGAGGAAAAG 3') and the reverse primer LS2 (5', ATTCCCAAACAACTCGACTC 3').

The D1/D2 PCR program consisted to one cycle at $94{ }^{\circ} \mathrm{C}$ for $3 \mathrm{~min}$, followed by 30 cycles $\left(95^{\circ} \mathrm{C}\right.$ for $1 \mathrm{~min}, 52^{\circ} \mathrm{C}$ for $1 \mathrm{~min}, 72^{\circ} \mathrm{C}$ for $1 \mathrm{~min}$ ), and a final extension at $72{ }^{\circ} \mathrm{C}$ for $10 \mathrm{~min}$. The amplified products were submitted directly for sequencing in order identify different yeast species involving in Ivorian cocoa fermentation.

\subsection{PCR-RFLP analysis and yeast molecular identification}

For RFLP analysis, PCR-amplified ITS1/ITS2 regions of 5.8S rDNA were digested with HhaI, HaeIII or HinfI (New England BioLabs) restriction enzymes. Reactions, composed of $10 \mu \mathrm{L}$ of ITS1/ITS2 PCR, $2 \mu \mathrm{L}$ of supplied buffer, $7.6 \mu \mathrm{L}$ of water and $0.4 \mu \mathrm{L}$ of each restriction enzyme, were incubated at $37{ }^{\circ} \mathrm{C}$ for $15 \mathrm{~min}$ and further analysed by electrophoresis in 1.3 $\%(\mathrm{w} / \mathrm{v})$ agarose gel in $0.5 \mathrm{X}$ TAE buffer. 
For molecular identification of isolated yeasts, PCR-amplified D1/D2 regions of $26 \mathrm{~S}$ rDNA were sequenced at BIOFIDAL (Lyon, France) using the Pseq D1/D2 primer (5' GGGCCATATCAATAAGC 3'). Sequences were then compared to the NCBI data Genbank using the BLAST program (http://blast.ncbi.nlm.nih.gov/Blast.cgi). Sequences showing a high percentage of identity ( $\geq 97 \%$ ) were considered as belonging to the same species.

\section{Results}

\section{Fermentation conditions and yeasts growth}

\subsection{Fermentation conditions}

The temperature of cocoa mass increased rapidly during $24 \mathrm{~h}$ to $72 \mathrm{~h}$ of fermentation time and then decreased progressively after this time for all local regions. However, the higher peak of temperature $\left(47^{\circ} \mathrm{C}\right)$ was obtained in Cavally after $48 \mathrm{~h}$ of fermentation; while the lower peak of temperature was recorded in San Pedro after $24 \mathrm{~h}$ of fermentation (Figure 1). Moreover, it also observed that Gbôklè and San Pedro reached maximal temperature after $24 \mathrm{~h}$ while Haut-Sassandra and Cavally reached this value at $48 \mathrm{~h}$, and Gôh and Tonkpi had a peak of temperature after $72 \mathrm{~h}$ of fermentation (Figure 1).

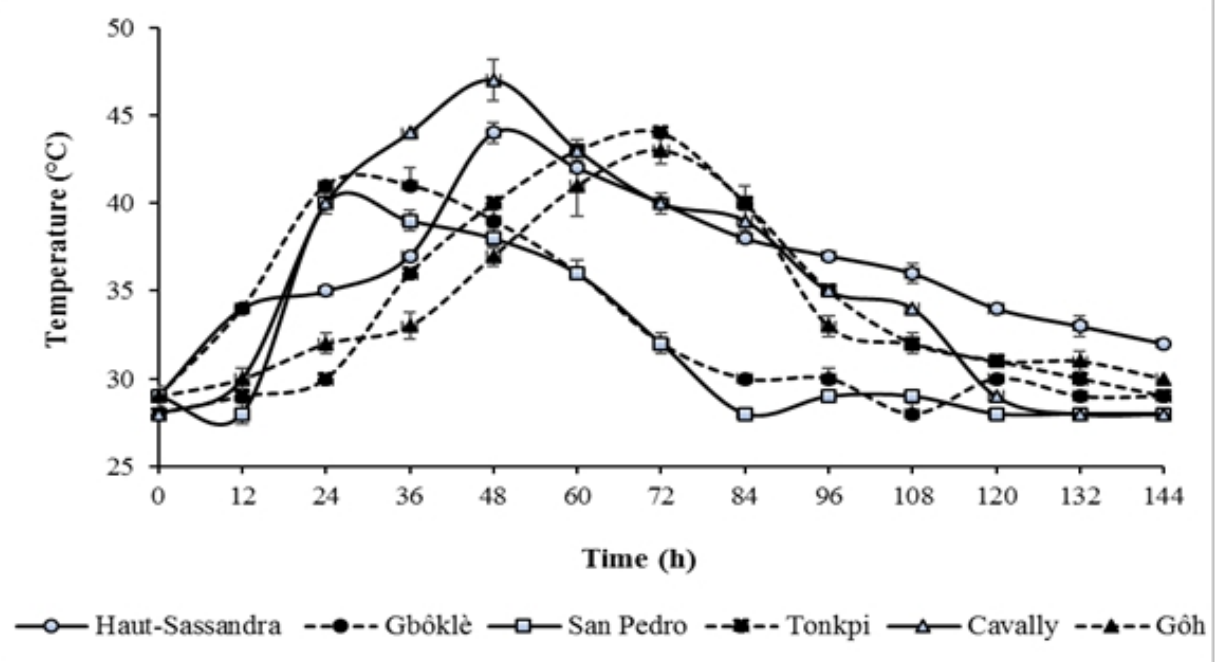

Figure 1. Evolution of temperature during cocoa heap fermentation.

Concerning the $\mathrm{pH}$, it raised progressively during all fermentation process, to 3.4 at the beginning of the process up to 7.7 at the end of process (Figure 2). However, during the first $60 \mathrm{~h}, \mathrm{pH}$ of cocoa pulp remain acid with values ranging between $3.8-4.9$. 


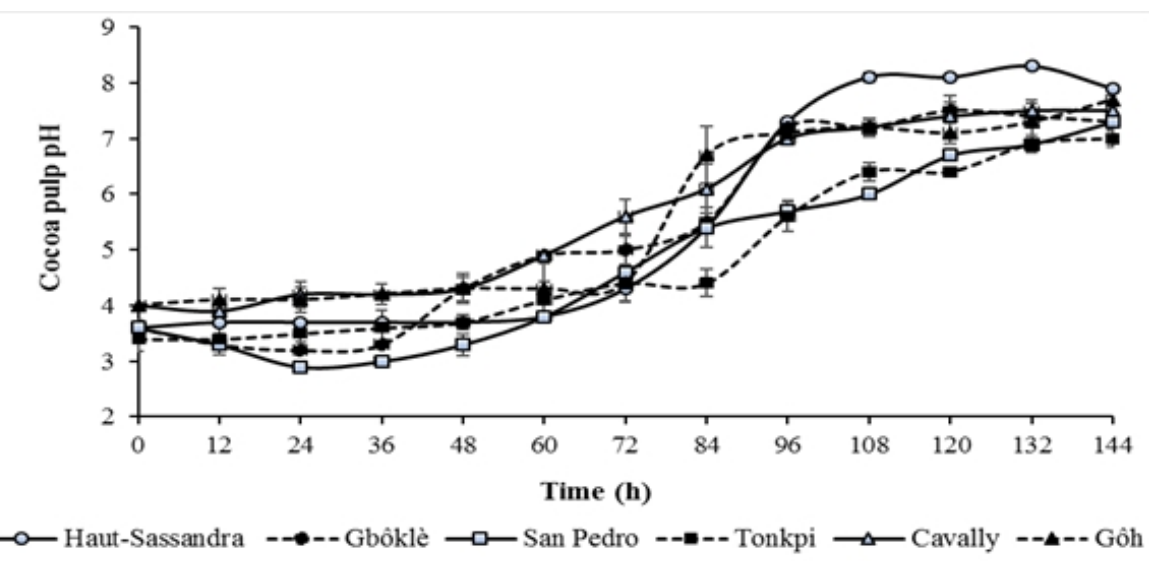

Figure 2. Evolution of cocoa pulp pH during cocoa heap fermentation.

The titratable acidity variation of cocoa pulp was similar for the six regions. However, the acidity value for the regions of Gbôklè, San Pedro, Haut-Sassandra, Cavally and Tonkpi increased until to reach a maximum value at $24 \mathrm{~h}$ of fermentation time. Only the region of Gôh recorded its higher titratable acidity at $12 \mathrm{~h}$ of fermentation time (Figure 3). The higher acidity value (4.43 meq/g of cocoa beans) was obtained in San Pedro while the lower acidity value (1.96 meq/g of cocoa beans) was recorded in Cavally. Regions of Gôh and Tonkpi were recorded the same maximum acidity value (2.06 meq/g of cocoa beans) but at different times of fermentation around 12 $\mathrm{h}$ and $24 \mathrm{~h}$, respectively (Figure 3 ).

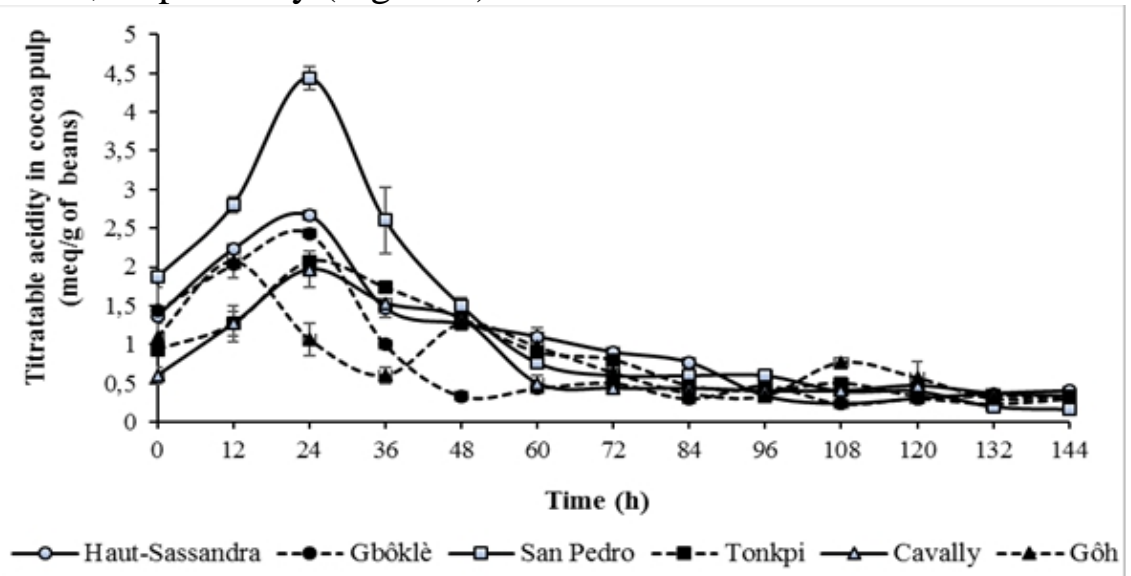

Figure 3. Evolution of titratable acidity of cocoa pulp during cocoa heap fermentation.

Concerning the quantity of pulp reducing sugars during cocoa fermentation in the six regions, the figure 4 showed a rapid decrease of reducing sugars quantity during $72 \mathrm{~h}$ of fermentation time. Indeed, it observed 77.35 to $87.32 \%$ of reducing sugars consumed in cocoa pulp for the six fermentations. 


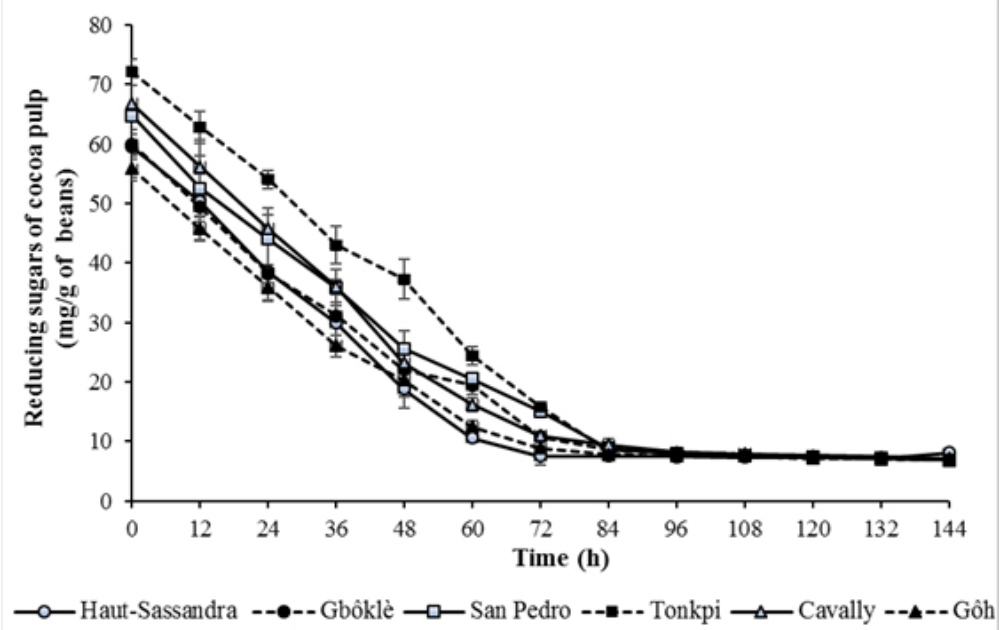

Figure 4. Evolution of reducing sugars of cocoa pulp during cocoa heap fermentation.

\subsection{Yeasts growth}

The yeasts growth kinetic (Figure 5) showed that the yeasts start the cocoa fermentation with $10^{4}-10^{5}$ even $10^{6} \mathrm{CFU} / \mathrm{g}$ until $10^{7}$ and $10^{8} \mathrm{CFU} / \mathrm{g}$ at 12-24 h. The occurrence time of yeasts during these six cocoa fermentations is $12 \mathrm{~h}-60 \mathrm{~h}$. The kinetic of yeasts growth concerning Cavally, Tonkpi, Gôh and Gbôklè regions is the same. Indeed, for these regions, it observed an increase of yeasts population during the first $24 \mathrm{~h}$ and decrease progressively after $24 \mathrm{~h}$ of fermentation. On the other hand, San Pedro and in HautSassandra showed different kinetics of growth. The yeasts growth kinetic from San Pedro region showed a slight increasing of yeasts populations during the first $24 \mathrm{~h}$ before to reach a peak at $36 \mathrm{~h}$ of fermentation time. As for yeasts growth kinetic from Haut-Sassandra region, it increases rapidly during the first $12 \mathrm{~h}$ and decreased rapidly until $48 \mathrm{~h}$ (Figure 5).

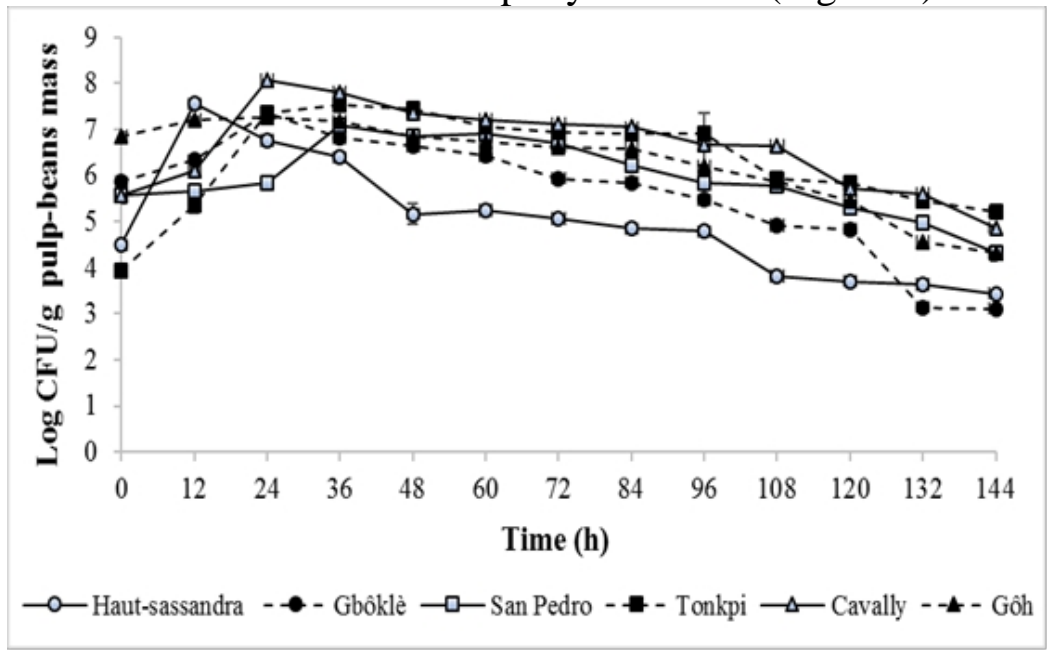

Figure 5. Yeasts growth dynamic during cocoa heap fermentation. 


\section{Analysis of yeasts diversity during cocoa fermentation}

During the cocoa fermentation process, 743 yeast strains were isolated for all six regions. The ITS1/ITS2 regions of 5,8S gene of these isolates were amplified, and cut with restriction enzyme.

Table 1. Length and RFLP analysis of ITS1/ITS2 region of 5.8S rDNA of yeast isolates involved in cocoa heap fermentation of the six major regions.

\begin{tabular}{|c|c|c|c|c|c|c|}
\hline \multirow[t]{2}{*}{ Region } & \multirow[t]{2}{*}{ Group } & \multirow{2}{*}{$\begin{array}{c}\text { Marker length } \\
\text { ITS1-5.8S-ITS2 (bp) }\end{array}$} & \multicolumn{3}{|c|}{ Restriction profile } & \multirow{2}{*}{$\begin{array}{r}\text { Number } \\
\text { of isolates }\end{array}$} \\
\hline & & & HaeIII (bp) & XhaI (bp) & HinfI (bp) & \\
\hline \multirow{4}{*}{ GBÔKLE } & $\mathrm{I}_{\mathrm{Gb}}$ & $400-500$ & $350+100$ & $250+150$ & $400-500$ & 11 \\
\hline & $\mathrm{II}_{\mathrm{Gb}}$ & 500 & 500 & 500 & 500 & 84 \\
\hline & $\mathrm{III}_{\mathrm{Gb}}$ & 600 & $450+100$ & $350+250$ & $200+200$ & 7 \\
\hline & $\mathrm{IV}_{\mathrm{Gb}}$ & 800 & $350+250+200$ & $500+300$ & $500+100$ & 11 \\
\hline \multirow{3}{*}{$\begin{array}{c}\text { HAUT- } \\
\text { SASSANDRA }\end{array}$} & IHS & 400 & 400 & 400 & 400 & 2 \\
\hline & IIHS & 500 & 500 & $300+200$ & $150+200$ & 8 \\
\hline & IIIHS & 800 & 800 & $500+300$ & $500+100$ & 109 \\
\hline \multirow{4}{*}{ SAN PEDRO } & IsP & $400-500$ & $400-500$ & $200+150$ & $400-500$ & 61 \\
\hline & IIIPP & 500 & 500 & $300+200$ & $150+200$ & 21 \\
\hline & IIISP & 600 & $400+200$ & 300 & $500+100$ & 17 \\
\hline & $\mathrm{IV}_{\mathrm{SP}}$ & 800 & $400+200$ & $400+200$ & $500+100$ & 21 \\
\hline \multirow{3}{*}{ TONKPI } & $\mathrm{I}_{\mathrm{T}}$ & 500 & $400+100$ & 500 & 250 & $\overline{106}$ \\
\hline & $\mathrm{II}_{\mathrm{T}}$ & 600 & $500+100$ & 600 & 300 & 17 \\
\hline & $\mathrm{IIIT}_{\mathrm{T}}$ & 800 & 800 & 800 & $400+200$ & 2 \\
\hline \multirow{3}{*}{ GÔH } & $\mathrm{IG}_{\mathrm{G}}$ & 500 & $400+100$ & $200+100$ & $400+100$ & 18 \\
\hline & $\mathrm{II}_{\mathrm{G}}$ & 600 & $500+100$ & $200+100$ & $300+150$ & 67 \\
\hline & $\mathrm{III}_{\mathrm{G}}$ & 800 & 800 & 800 & $400+200$ & 46 \\
\hline \multirow{3}{*}{ CAVALLY } & IC & 500 & $400+100$ & $300+150$ & $200+250$ & 85 \\
\hline & $\mathrm{II}_{\mathrm{C}}$ & 600 & $450+150$ & 600 & $500+100$ & 4 \\
\hline & IIIC & 800 & $400+200$ & 800 & $400+200$ & 46 \\
\hline
\end{tabular}

bp: base pairs; HaeIII, XhaI and HinfI: restristion enzymes.

The results of different restrictions profiles generated are presented in table 1. Gbôklè and San Pedro regions presented four (4) different restriction profiles while Haut-Sassandra, Cavally, Gôh and Tonkpi regions presented three (3) restriction profiles (Table 1). Almost all restrictions profiles obtained were different between them and different of one region and another.

Analysis of sequences of D1/D2 domain of 26S gene of yeast strains has allowed to identify yeasts species involved in cocoa fermentation of the studied regions. Eleven (11) species were identified in the six local regions, including $P$. kudriavzevii, $P$. kluyveri, S. cerevisiae, $P$. manshurica, $H$. uvarum, D. hansenii, K. ohmeri, Debaryomyces sp., C. humilis / K. exigua, $H$. uvarum / H. opuntiae and C. tropicalis. The distribution of these species for each local region is presented in table 2. Results indicated that $P$. 
kudriavzevii, Saccharomyces cerevisiae and P. kluyveri were mainly species involved in cocoa fermentation for all local regions (Table 2). Moreover, a weakest diversity was observed in Cavally region with only three species while a highest diversity was obtained from Tonkpi region with six species (Table 2).

The RLFP analysis has allowed to reveal an intraspecific diversity for identified species. Indeed, the results showed that some identified species presented several restrictions profiles while other presented only one (Table 3). The species as Pichia kudriavzevii, Pichia kluyveri, Pichia manshurica, Saccharomyces cerevisiae and Hanseniaspora uvarum revealed several restrictions profiles for the same species. Pichia kudriavzevii and Saccharomyces cerevisiae showed a large intraspecific diversity with 7 different restriction profiles. Pichia kluyveri revealed 3 different restriction profiles. Pichia manshurica and Hanseniaspora uvarum revealed 2 restriction profiles (Table 3 ). 
Table 2. Distribution of yeast strains involved in cocoa heap fermentation at different local major regions of Ivory Coast.

\begin{tabular}{|c|c|c|c|c|c|c|}
\hline Region & Haut-Sassandra & Gbôklè & San-Pedro & Tonkpi & Cavally & Gôh \\
\hline \multirow[t]{6}{*}{ Species } & P. kluyveri (72) & P. kudriavzevii (62) & P. kluyveri (61) & P. kudriavzevii (98) & P. kudriavzevii (85) & P. kudriavzevii (67) \\
\hline & H. uvarum (37) & S. cerevisiae $\mathbf{( 4 0 )}$ & S. cerevisiae (21) & S. cerevisiae $(\mathbf{9})$ & S. cerevisiae (46) & H. uvarum (24) \\
\hline & S. cerevisiae (8) & P. manshurica (11) & P. kudriavzevii (21) & P. manshurica (8) & D. hansenii (4) & S. cerevisiae (22) \\
\hline & K. ohmeri (2) & P. kluyveri (5) & Debaryomyces sp. (17) & C. humilis / K. exigua (6) & & P. kluyveri (18) \\
\hline & & & & H. uvarum/H. opuntiae (2) & & \\
\hline & & & & C. tropicalis $(\mathbf{2})$ & & \\
\hline
\end{tabular}

The values in bracket represent the number of the species founded in the region. P. kluyveri: Pichia kluyveri; H. uvarum: Hansenisapora uvarum; S. cerevisiae: Saccharomyces cerevisiae; K ohmeri: Kodamaea ohmeri; P. kudriavzevii: Pichia kudriavzevii; P. manshurica: Pichia manshurica; C. humilis / K. exigua: Candida humilis / Kazachstania exigua; H. uvarum/H. opuntiae: Hanseniaspora uvarum/ Hanseniaspora opuntiae; C. tropicalis: Candida tropicalis; D. hansenii: Debaryomyces hansenii.

Table 3. Restriction profiles of yeast strains involved in cocoa heap fermentation.

\begin{tabular}{llc}
\hline Strains & Restriction profiles & $\begin{array}{c}\text { Number of } \\
\text { strains }\end{array}$ \\
\hline Pichia kudriavzevii & & 333 \\
Pichia kluyveri & $\mathrm{II}_{\mathrm{Gb}} ; \mathrm{III}_{\mathrm{Gb}} ; \mathrm{IV}_{\mathrm{Gb}} ; \mathrm{II}_{\mathrm{SP}} ; \mathrm{I}_{\mathrm{T}} ; \mathrm{II}_{\mathrm{G}} ; \mathrm{I}_{\mathrm{C}}$ & 156 \\
Saccharomyces cerevisiae & $\mathrm{III}_{\mathrm{HS}} ; \mathrm{I}_{\mathrm{SP}} ; \mathrm{I}_{\mathrm{G}} ; \mathrm{IV}_{\mathrm{Gb}}$ & 141 \\
Hanseniaspora uvarum & $\mathrm{II}_{\mathrm{Gb}} ; \mathrm{IV}_{\mathrm{Gb}} ; \mathrm{II}_{\mathrm{HS}} ; \mathrm{IV}_{\mathrm{SP}} ; \mathrm{II}_{\mathrm{T}} ; \mathrm{III}_{\mathrm{G}} ; \mathrm{III}_{\mathrm{C}}$ & 61 \\
Pichia manshurica & $\mathrm{III}_{\mathrm{HS}} ; \mathrm{III}_{\mathrm{G}}$ & 19 \\
Debaryomyces sp & $\mathrm{I}_{\mathrm{Gb}} ; \mathrm{I}_{\mathrm{T}}$ & 17 \\
Candida humilis / Kazachstania exigua & $\mathrm{III}_{\mathrm{SP}}$ & 6 \\
Debaromyces hansenii & $\mathrm{II}_{\mathrm{T}}$ & 4 \\
Kodamaea ohmeri & $\mathrm{II}_{\mathrm{C}}$ & 2 \\
Hanseniaspora uvarum / Hanseniaspora opuntiae & $\mathrm{I}_{\mathrm{HS}}$ & 2 \\
Candida tropicalis & $\mathrm{II}_{\mathrm{T}}$ & 2 \\
\hline
\end{tabular}




\section{Discussion}

Cocoa fermentation is a spontaneous process necessary in postharvest process in cocoa. The spontaneous nature of cocoa bean fermentations may be the source of microbial variation, and hence of variable end-product quality (Maura, et al., 2016). In this study, the diversity of yeasts, initiators of process, was studied in order to explain the variability of cocoa beans quality from Ivory Coast and identify keys species for selecting appropriate yeasts starters for Ivorian cocoa fermentation. At first sight, physicochemical parameters are determined to appreciate the activity of cocoa microflora particularly yeasts involved in the fermentative process.

Our study recorded temperatures values between $40-47{ }^{\circ} \mathrm{C}$ at different times of fermentation. Although, some studies reported values reach never above $42{ }^{\circ} \mathrm{C}$ (Kouamé, 2017. Visintin, Alessandria, Valente, Paola Dolci, \& Cocolin, 2016), most studies report values increasing up to $50{ }^{\circ} \mathrm{C}$ during cocoa beans fermentation (Ardhana \& Fleet, 2003. LagunesGalvez, Loiseau, Paredes, Barel, \& Guiraud, 2007). In generally, increase of temperature during cocoa fermentation process is induce by the conversion of the sugars to ethanol by yeasts, then ethanol to acetic acid by acetic acid bacteria which are exothermic reactions (Schwan \& Wheals, The microbiology of cocoa fermentation and its role in chocolate quality, 2004). Consequently, intensity of peak of temperature is linked to the intensity of these reactions and therefore to the capacity of yeasts and acetic acid bacteria to produce hight amount of ethanol and acetic acid respectively. Since ethanol and acetic acid are necessary for obtaining quality cocoa, the Cavally region in which the higher temperature peak $\left(47^{\circ} \mathrm{C}\right)$ was recorded could allow production of quality cocoa beans and selection of yeasts strains with high ethanol production capacity for the standardization of the cocoa fermentation process.

During the cocoa fermentation, the pulp $\mathrm{pH}$ change acid to basic. The same result was reported by several studies (Guehi, Dabone, Ban-Koffi, Kra, \& Zahouli, 2010. Mahazar, et al., 2015. Ouattara, et al., 2016). The increasing of pulp pH could be due to the catabolism of citric acid by yeasts and lactic acid bacteria which offer favorable conditions for the other bacteria growth notably Bacillus and acetic acid bacteria (Leal, Gomes, Efraim, Tavares, \& Figueira, 2008. Crafack, et al., 2013) which are also necessary to fermentation process (Soumahoro, et al., 2015. Yao, Goualié, Ouattara, \& Niamké, 2017). Moreover, the citrate metabolism is known to have a benefic effect on fermentation process because it leads to produce some aroma molecules such as acetoin which are desirable flavor in fermentation process (Illeghems, Weckx, \& De Vuyst, 2015).

The decreasing of reducing sugars observed in the six regions, during the first $72 \mathrm{~h}$ of fermentation time, indicates the effectiveness of the 
fermentative activity of cocoa microflora notably yeasts which convert these sugars to ethanol (Ho V. , Zhao, Srzednicki, \& Fleet, 2013). A similar rapid decreasing trend was observed by Afoakwa, Kongor, Takrama, \& Budu, (2013) in Ghana. However, it also reported that, during the first hours of fermentation time, some yeasts, lactic acid bacteria and acetic acid bacteria convert sugars in acids (Swiegers, Bartowsky, Henschke, \& Pretorius, 2005. Papalexandratou, Camu, Falony, \& De Vuyst, 2011. De Vuyst \& Weckx, The cocoa bean fermentation process: from ecosystem analysis to starter culture development, 2016), which explain the increasing titratable acidity during the first $24 \mathrm{~h}$. These acids produced in the pulp diffuse into the beans and subsequently induce important biochemical reactions leading to well fermented cocoa beans (Afoakwa, Kongor, Takrama, \& Budu, 2013). This diffusion into cotyledons gives rise to a decrease of acids concentrations in pulp, which explain the decrease of titratable acidity after $24 \mathrm{~h}$ of fermentation.

Isolation of yeasts was carried out to identify the different species involved into each local region. Thus, the yeasts growth dynamics during cocoa fermentation showed that yeasts are present during fermentation process. No lag phase was observed during these fermentative processes as reported by (Samagaci, G., Goualié, \& Niamke, 2014). This is probably due to suitable growth conditions for yeasts prevailing in the initial phase of cocoa fermentation (Nielsen, et al., 2007). Indeed, high reducing sugars concentrations in cocoa pulp (55.91-72.09 mg/g) at the beginning of fermentation were recorded for all regions. Moreover, the $\mathrm{pH}$ (3.8-4.9) of each local region, is quite remaining acid during the first $60 \mathrm{~h}$ of fermentation time. This could be explained the optimal occurrence of yeasts during 12-60 h of fermentation time. These results corroborate those of Ho, Zhao, \& Fleet, (2014) which have observed yeasts occurrence during 48 h-72 $\mathrm{h}$ of cocoa fermentation. According to these authors, yeasts are cocoa fermentation process initiators and consider as necessary at this process (Ho, Zhao, \& Fleet, 2014). Indeed, the primary activity of yeasts is the conversion of reducing sugars to ethanol and $\mathrm{CO}_{2}$ (Schwan \& Wheals, The microbiology of cocoa fermentation and its role in chocolate quality, 2004. LagunesGalvez, Loiseau, Paredes, Barel, \& Guiraud, 2007). This activity is very crucial to cocoa fermentation because ethanol produced by yeasts is then oxidized by acetic acid bacteria to acetic acid which, by its diffusion into cotyledons, contribute to the formation of aroma precursors of chocolate (Thompson, Miller, Lopez, \& Camu, 2013).

During the fermentation process, 743 yeasts were isolated from the six regions. The analysis of RLFP and sequencing of domain D1/D2 of 26S gene of these isolates showed 18 restriction profiles and 11 yeasts species respectively. This indicates existence of a diversity in yeasts population 
involved in Ivorian cocoa fermentation. In addition, our results indicated that the fermentation process was dominated by Pichia kudriavzevii, Pichia kluyveri and Saccharomyces cerevisiae at rate prevailing of $84,78 \%$. The high prevailing of these species could be due to ability of these species to withstand the stressful conditions from cocoa fermentation (Daniel, Vrancken, Takrama, Camu, \& De Vuyst, 2009. De Vuyst, Lefeber, Papalexandratou, \& Camu, 2010. Pereira, Miguel, Ramos, \& Schwan, 2012. Samagaci, Ouattara, Niamké, \& Lemaire, 2016. Also, the dominance of these species is an interesting result because most studies, concerning the control of cocoa fermentation by yeasts, reported the use of these three species as appropriate starter cultures (Crafack, et al., 2013. Meersman, et al., 2016. Pereira, et al., 2017).

Indeed, some Pichia kudriavzevii used as starter, successfully carried out the fermentation process, with efficient sugar metabolism and ethanol formation. Their metabolic activity during the fermentation process influenced the final volatile fraction of fermented cocoa beans (Pereira, et al., 2017). Thus, the dominance of Pichia kudriavzevii in Gbôklè, Tonkpi, Cavally and Gôh regions will allow to obtain cocoa beans fermented from these regions with excellent aromas.

Moreover, according to Crafack, et al. (2013), Pichia kluyveri influences positively the flavor profile of cocoa beans and presents great pectinolytic activity to degrade pectin of the cocoa pulp. Thus HautSassandra and San Pedro, the two regions dominated by Pichia kluyveri, could be susceptible to give cocoa beans fermented with good flavor profile. Besides, Haut-Sassandra and San Pedro are neighbor regions and this proximity could explain the dominance of the same species, Pichia klyuveri in these regions.

Concerning Saccharomyces cerevisiae, Meersman, et al. (2016) showed that thermotolerant hybrid strains of Saccharomyces cerevisiae would be able to increase acetate ester production necessary to aroma formation of chocolate. Thus, Saccharomyces cerevisiae strains which prevail in all regions can be exploited in order to identify appropriate starters cultures to cocoa fermentation or others food fermentations.

Besides the predominant species, the occurrence of some species at low prevalence notably Candida tropicalis is to underline because known to influence quality and safety cocoa. Indeed, the addition of Candida sp. on cocoa beans fermentation inhibit the growth of pathogenic microorganisms. Candida sp.-fermentation ensured both the quality and safety of the end product (Mahazar, et al., 2015). Thus, the prevalence of Candida tropicalis from Tonkpi region could contribute to guaranty both the cocoa quality and cocoa safety. 
Eleven (11) species were involved in cocoa heap fermentations of the six Ivorian major local cocoa producing regions studied. This heterogeneity of yeasts population implicated into cocoa bean fermentation was also shown in studies around the world (Nielsen, Hønholt, Tano-Debrah, \& Jespersen, 2005. Daniel, Vrancken, Takrama, Camu, \& De Vuyst, 2009. AranaSánchez, et al., 2015). However, some yeast species isolated from our investigations were differents from those previously isolated in Ivory Coast. Indeed, Pichia galeiformis, Galactomyces geotrichum and Wickerhamomyces anomalus were isolated in cocoa fermentation from Me region (Ivory Coast) (Koné, et al., 2016). Candida intermedia, Candida nacodendra, and Hanseniaspora guilliermondii were isolated in cocoa fermentation from Agneby-Tiassa region (Ivory Coast) (Samagaci, Ouattara, Niamké, \& Lemaire, 2016). In addition, Torulaspora delbrueckii, Candida ethanolica and Schizosaccharomyces pombe are also be detected recently in Ivorian cocoa fermentation by Visintin, Alessandria, Valente, Paola Dolci, \& Cocolin, (2016). All these results indicate the occurrence of a diversity and a variability of yeast microflora involved in Ivorian cocoa fermentation to one local region to another. This yeast species diversity and variability would be responsible to the variability of cocoa beans quality observed in Ivory Coast. Because, yeast species involved into each producing region could display a specific role that could impact cocoa beans quality in fine chocolate produced as reported above.

Analysis of RLFP profiles of species identified allowed to class yeast species in two groups. Firstly, yeast species which present one restriction profile as reported by Zarzoso, Belloch, Uruburul, \& Quero, (1999) and (Schwan, Almeida, Souza-Dias, \& Jespersen, 2007). Indeed, theses authors demonstrated that one restriction profile is specific of one species. However, some yeast species notably Pichia kudriavzevii, Saccharomyces cerevisiae, Pichia klyuveri, Pichia manshurica and Hanseniaspora uvarum presented several restriction profiles constituting the second group. Similar results were reported by Samagaci, Ouattara, Niamké, \& Lemaire, (2016) who showed 2 restrictions profiles for Candida tropicalis, Candida nacondendra and Hanseniaspora uvarum. Also, some authors reported great intraspecies variation among populations of Pichia kluyveri Saccharomyces cerevisiae and Pichia kudriavzevii respectively, isolated to cocoa fermentations (Jespersen, Nielsen, Hønholt, \& Jakobsen, 2005. Meersman, et al., 2013. Pereira, et al., 2017). Taken together, our results indicate occurrence an intraspecific diversity within yeasts population. This intraspecific diversity could be exploited for the choosing appropriate starter cultures to resolve the variability problem of cocoa quality, through the standardization of cocoa fermentation. Indeed, within group strains of a same species exist subdivisions which distinguish them by their genotypic and/or phenotypic 
features. The differentiation occurs when the species undergo significant mutations generated by natural processes, such as sexual reproduction, changes in ploidy, transposons, genetic recombination or horizontal gene transfer (Steensels, et al., 2014). (These natural mutations can form strains with important fermentative characteristics, which can be exploited for selecting appropriate starter cultures. Thus, the strains of Pichia kudriavzevii, Pichia kluyveri and Saccharomyces cerevisiae, which present a great intraspecific diversity and more abundant in this study, constitute some potential ways concerning starters research for the control of fermentative cocoa process still spontaneous in Ivory Coast.

\section{Conclusion}

The results of this study indicate that it exists a molecular diversity of yeasts involved in the fermentation of Ivorian cocoa, with a predominance of Pichia kudriavzevii, Saccharomyces cerevisiae and Pichia kluyveri. This diversity of yeast species, varying one local region to another, can explain the variability of cocoa beans quality in Ivory Coast. Moreover, the great intraspecific diversity of these predominant yeast species indicate that some strains of the same species can present different characteristics which can be used for selecting appropriate starter cultures in industry. Thus, considering the crucial role of yeasts in cocoa fermentation, it would arrange to research yeast starters to control the fermentative cocoa process as realized already in beer, wine and bread industries. This would contribute to resolve the problem of the variability of cocoa beans quality which cause huge economic loss in Ivory Coast.

\section{References:}

1. Afoakwa, E. O., Kongor, J. E., Takrama, J. F., \& Budu, A. S. (2013). Changes in acidifiation, sugars and mineral composition of cocoa pulp during fermentation of pulp pre-conditioned cocoa (Theobroma cacao) beans. International Food Research Journal, 20(3), 12151222.

2. Agbo, N. C., Uebersax, M., \& Hosfieldn, G. (1985). An efficient extraction technique of sugars from dry edible beans (Phaseolus vulgaris L.) and estimation HPLC. Anna University National, 20, 167-187.

3. ANADER. (2014). Agriculture: the coffee-cocoa office will revive the coffee production. Abidjan: Fraternité matin, Friday, 21 november 2014 09:45 am. .

4. AOAC. (1990). Official methods of analysis. Association of Official Analytical Chemist. Washington DC. 
5. Arana-Sánchez, A., Segura-García, L. E., Kirchmayer, M., OrozcoÁvila, I., Lugo-Cervantes, E., \& Gschaedler-Mathis, A. (2015). Identification of predominant yeasts associated with artisan Mexican cocoa fermentations using culture-dependent and culture-independent approaches. Word J. Microbiol. Biotechnol., 31, 359-369.

6. Ardhana, M. M., \& Fleet, G. H. (2003). The microbial ecology of cocoa bean fermentations in Indonesia. International Journal Food Microbiology, 86, 87-99.

7. Bernfeld, D. (1955). Amylase $\beta$ et $\alpha$, In method in enzymology . Colowick S.P. and Kaplan N.O. Academic Press , 149-154.

8. Crafack, M., Mikkelsen, M., Saerens, S., Knudsen, M., Blennow, A., Lowor, S., . . . Nielsen, D. (2013). Influencing cocoa flavor using Pichia Kluyveri and Kluyveromyces marxianus in a defined mixed starter culture for cocoa fermentation. International Journal of Food Microbiology, 167, 103-116.

9. Daniel, H., Vrancken, G., Takrama, J., Camu, N. D., \& De Vuyst, L. (2009). Yeast diversity of Ghanaian cocoa bean heap fermentations. FEMS Yeast Res., 9, 774-783.

10. De Vuyst, L., \& Weckx, S. (2016). The cocoa bean fermentation process: from ecosystem analysis to starter culture development. Journal of Applied Microbiology, 13 p.

11. De Vuyst, L., Lefeber, T., Papalexandratou, Z., \& Camu, N. (2010). The functional role of lactic acid bacteria in cocoa bean fermentation. In: Mozzi, F., Raya, R.R., Vignolo, G.M. (Eds.), Biotechnology of Lactic Acid Bacteria - Novel Applications. Wiley-Bl.

12. Guehi, S., Dabone, S., Ban-Koffi, L., Kra, D., \& Zahouli, G. (2010). Effect of turning beans and fermentation method on the acidity and physical quality of raw cocoa beans. Adv. Journal. Food Science Technology , 2, 163-171.

13. Hamdouche, Y., Guehi, T., Durand, N., Kedjebo, K. B., Montet, D., \& Meile, J. C. (2015 ). Dynamics of microbial ecology during cocoa fermentation and drying: towards the identification of molecular markers. Food Control, 48, 117-122.

14. Hansen, C., Del Olmo, M., \& C., B. (1998). Enzyme activities in cocoa beans during fermentation. Journal of the Science of Food and Agriculture, 77, 273-281.

15. Ho, V. T., Zhao, J., \& Fleet, G. (2014). Yeasts are essential for cocoa fermentation . International Journal of Food Microbiology, 174, 7287.

16. Ho, V., Zhao, J., Srzednicki, G., \& Fleet, G. (2013). The Functional Role of Microorganisms in Cocoa Bean Fermentation. International Symposium on Agric-Foods for Health and Wealth, 83-91. 
17. Hoffman, C. S. (2001). Preparation of yeast DNA. Dans Current Protocols in Molecular Biology (pp. 39 (IV:13.11:13.11.1-13.11.4).

18. Holm, C., Aston, J., \& Douglas, K. (1993). The effects of the organic-acids in cocoa on the flavor of chocolate. J. Sci. Food Agric., 61, 65-71.

19. Illeghems, K., Weckx, S., \& De Vuyst, L. (2015). Applying metapathway analyses through metagenomics to identify the functional properties of the major bacterial communities of a single spontaneous cocoa bean fermentation process sample. Food Microbiology, 50, 5463.

20. Jespersen, L., Nielsen, D. S., Hønholt, S., \& Jakobsen, M. .. (2005). Occurrence and diversity of yeasts involved in fermentation of West African cocoa beans. FEMS Yeast Research, 5, 441-453.

21. Koné, K., Guéhi, T., Durand, N., Ban-Koffi, L., Berthiot, L., Tachon, F., . . . Montet, D. (2016). Contribution of predominant yeasts to the occurrence of aroma compounds during cocoa bean fermentation. Food Res Int., 89, 910-917.

22. Kostinek, M., Ban-Koffi, L., Ottah-Atikpo, M., Teniola, D., Schillinger, U., Holzapfel, W., \& Franz, C. (2008). Diversity of predominant lactic acid bacteria associated with cocoa fermentation in Nigeria. Curr Microbiol, 56, 306-314.

23. Kouame, L., Goualie, B. G., Adom, J. N., Koua, G., Ouattara, H. G., Doue, G., \& Niamke, L. S. (2015). Diversity of microbial strains involved in cocoa fermentation from Sud- Comoé (Ivory Coast) based on biochemical properties. European Scientific Journal, 11(18), 69-85.

24. Kouamé, M. L. (2017). Diversité et cartographie de la microflore régionale du cacao de Côte d'Ivoire : caractérisation biochimique et moléculaire des souches microbiennes de type fermentaire. Thèse unique de doctorat, Université Felix Houphouët-Boigny. Abidjan.

25. Lagunes-Galvez, S., Loiseau, G., Paredes, J., Barel, M., \& Guiraud, J. (2007). Study on the microflora and biochemistry of cocoa fermentation in the Dominican Republic. Int J. Food Microbiol, 114(1), 124-130.

26. Leal, G. A., Gomes, L. H., Efraim, P., Tavares, F. C., \& Figueira, A. (2008). Fermentation of cacao (Theobroma cacao L.) seeds with a hybrid Kluyveromyces marxianus strain improved product quality attributes. FEMS Yeast Research, 8, 788-798.

27. Lopez, A. S., \& Dimick, P. S. (1995). Cocoa fermentation. In: Reed, G., Nagodawithana, T. W. (Eds.), Enzymes, Biomass, Food and Feed. VCH, Weinheim., 561-577. 
28. Mahazar, N. H., Sufian, N. F., Meor, H. A., Norhayati, H., Mathawan, M., \& Rukayadi, Y. (2015). Candida sp. as a starter culture for cocoa (Theobroma cacao L.) beans fermentation. International Food Research Journal, 22, 1783-1787.

29. Maura, Y. F., Balzarini, T., Borges, P. C., P., E., De Vuyst, L., \& Daniel, H.-M. (2016). The environmental and intrinsic yeast diversity of Cuban cocoa bean heap fermentations. International Journal of Food Microbiology, 233, 34-43.

30. Meersman, E., J., S., Mathawan, M., Wittocx, P., Saels, V., Struyf, N., . . . Verstrepen, K. (2013). Detailed analysis of the microbial population in Malaysian spontaneous cocoa pulp fermentations reveals a core and variable microbiota. PLoS One, 8(12), 8159.

31. Meersman, E., Steensels, J., Struyf, N., Paulus, T., Saels, V., Mathawan, M., . . . Verstrepen, K. J. (2016). Tuning chocolate flavour through development of thermotolerant Saccharomyces cerevisiae starter cultures with increased acetate ester production. Appl. Environ. Microbiol., 82(2), 732-746.

32. Nielsen, D., Hønholt, S., Tano-Debrah, K., \& Jespersen, L. (2005). Yeast populations associated with Ghanaian cocoa fermentations analyzed using denaturing gradient gel electrophoresis (DGGE). Yeast, 22(4), 271-284.

33. Nielsen, D., Teniola, O., Ban-Koffi, L., Owusu, M., Andersson, T., \& Holzapfel, W. (2007). The microbiology of Ghanaian cocoa fermentations analyzed using culture-dependent and culture independent methods. Int. J. Food Micro., 114, 168-86.

34. Ouattara, D. H., Ouattara, H. G., Adom, J. N., Goualié, B. G., Koua, G. A., Doué, G. G., \& Niamke, S. (2016). Screening of lactic acid bacteria capable to breakdown citric acid during Ivorian cocoa fermentation and response of bacterial strains to fermentative conditions. British Biotechnology Journal, 10(3), 1-10.

35. Ouattara, H. G., Ban-Koffi, L., Karou, G. T., Sangare, A., Niamke, S. L., \& Diopoh, J. K. (2008). Implication of Bacillus sp. in the production of pectinolytic Enzymes during cocoa fermentation. World Journal of Microbiology and Biotechnology, 24, 1753-1760.

36. Papalexandratou, Z., \& De Vuyst, L. (2011). Assessment of the yeast species composition of cocoa bean fermentations in different cocoaproducing regions using denaturing gradient gel electrophoresis. FEMS Yeast Res , 11(7), 564-574.

37. Papalexandratou, Z., Camu, N., Falony, G., \& De Vuyst, L. (2011). Comparison of the bacterial species diversity of spontaneous cocoa bean fermentations carried out at selected farms in Ivory Coast and Brazil . Food Microbiol. , 28, 964-973. 
38. Pereira, G., Alvarez, J. P., Neto, D. P., Soccol, V. T., Tanobe, V. O., Rogez, H., . . R. R., S. C. (2017). Great intraspecies diversity of Pichia kudriavzevii in cocoa fermentation highlights the importance of yeast strain selection for flavor modulation of cocoa beans. LWT-Food Science and Technology. In Press.

39. Pereira, G., Miguel, M., Ramos, C., \& Schwan, R. (2012). Microbiological and physicochemical characterization of small-scale cocoa fermentations and screening of yeast and bacterial strains to develop a defined starter culture. Appl. Environ. Microbiol., 78(15), 5395-5405.

40. Roelofsen, P. (1958). Fermentation, drying and storage of cacao beans. Adv. Food Res. Int., 8, 225-296.

41. Romero-Cortes, T., Robles-Olvera, V., Rodriguez-Jimenes, G., \& Ramírez-Lepe, M. (2012). Isolation and characterization of acetic acid bacteria in cocoa fermentation. African Journal of Microbiology Research , 6(2), 339-347.

42. Samagaci, L., G., O. H., Goualié, B. G., \& Niamke, S. L. (2014). Growth capacity of yeasts potential starter strains under cocoa fermentation stress conditions in Ivory Coast. Emirates Journal of Food and Agriculture, 26, 861 -870.

43. Samagaci, L., Ouattara, H., Niamké, S., \& Lemaire, M. (2016). Pichia kudrazevii and Candida nitrativorans are the most welladapted and relevant yeast species fermenting cocoa in AgnebyTiassa, a local Ivorian cocoa producing region . Food Research International, 89, 773-780.

44. Schwan, R. F., \& Wheals, A. E. (2004). The microbiology of cocoa fermentation and its role in chocolate quality. Crit Rev Food Sci Nutr., 44(4), 205-221.

45. Schwan, R. F., Almeida, E. G., Souza-Dias, M. A., \& Jespersen, L. (2007). Yeast diversity in rice-cassava fermentations produced by the indigenous Tapirapé people of Brazil . FEMS Yeast Res., 7, 966-972.

46. Schwan, R., Rose, A., \& Board, R. (1995). Microbial fermentation of cocoa beans, with emphasis on enzymatic degradation of the pulp . J. Appl. Bacteriol. Symp. Sup., 79, 96-107.

47. Senanayake, M., Jansz, E., \& Buckle, K. (1997). Effect of different mixing intervals on the fermentation of cocoa beans. J. Sci. Food Agric., 74, 42-48.

48. Soumahoro, S., Ouattara, H., Goualié, B. G., Koua, G., Doue, G., \& Niamke, S. (2015). Occurrence of high acetic acid-producing bacteria in Ivorian cocoa fermentation and analysis of their response to fermentative stress. American Journal of Bioscience, 3(3), 70-79. 
49. Steensels, J., Snoek, T., Meersman, E., Nicolino, M. P., Voordeckers, K., \& Verstrepen, K. J. (2014). Improving industrial yeast strains: exploiting natural and artificial diversity. FEMS Microbiology Reviews, 1-49.

50. Swiegers, J., Bartowsky, E., Henschke, P., \& Pretorius, I. (2005). Yeast and bacterial modulation of wine aroma and flavor. Aust. J. Grape Wine Res., 11, 139-173.

51. Thompson, S., Miller, K., Lopez, A., \& Camu, N. (2013). Cocoa and coffee. In: Doyle, M.P., Buchanan, R.L. (Eds.), Food Microbiology: Fundamentals and Frontiers, 4th ed. ASM Press, Washington, DC, pp. 881-889.

52. Verstrepen, K., Van Laere, S., Vanderhaegen, B., Derdelinckx, G., Dufour, J., Pretorius, I., . . . Delvaux, F. (2003). Expression levels of the yeast alcohol acetyltransferase genes ATF1, LgATF1, and ATF2 control the formation of a broad range of volatile esters. Appl. Environ. Microbiol., 69, 5228-5237.

53. Visintin, S., Alessandria, V., Valente, A., Paola Dolci, P., \& Cocolin, L. (2016). Molecular identification and physiological characterization of yeasts, lactic acid bacteria and acetic acid bacteria isolated from heap and box cocoa bean fermentation in West Africa. International Journal of Food Microbiology, 216, 69-78.

54. Yao, W., Goualié, B., Ouattara, H., \& Niamké, S. (2017). Growth capacity of bacillus potential starter strains isolated from cocoa beans fermentation under culture stress conditions. Chemistry \& Chemical Engineering, Biotechnology, Food Industry, 18 (2), 201-211.

55. Zarzoso, E. B., Belloch, C., Uruburul, F., \& Quero, A. (1999). Identification of yeasts by RFLP analysis of the 5.85 rRNA gene and the two-ribosomal internal transcribed spacers. International Journal of Systematic Bacteriology, 49, 329-337. 